\title{
Importance of active layer freeze-thaw cycles on the riverine dissolved carbon export on the Qinghai-Tibet Plateau permafrost region
}

Chunlin Song ${ }^{1,2}$, Genxu Wang ${ }^{\text {Corresp }}, 1$, Tianxu Mao ${ }^{3}$, Xiaopeng Chen ${ }^{4}$, Kewei Huang ${ }^{1,2}$, Xiangyang Sun ${ }^{1}, \mathrm{ZhaOyong}$ Hu

${ }^{1}$ Institute of Mountain Hazards and Environment, Chinese Academy of Sciences, Chengdu, China

2 University of Chinese Academy of Sciences, Beijing, China

${ }^{3}$ Guizhou University, Guiyang, China

4 Shanxi Agricultural University, Jinzhong, China

Corresponding Author: Genxu Wang

Email address: wanggx@imde.ac.cn

The Qinghai-Tibet Plateau (QTP) is experiencing severe permafrost degradation, which can affect the hydrological and biogeochemical processes. Yet how the permafrost change affects riverine carbon export remains uncertain. Here we investigated the seasonal variations of dissolved inorganic and organic carbon (DIC and DOC) during flow seasons in a watershed located in the central QTP permafrost region. The results showed that riverine DIC concentration s $\left(27.81 \pm 9.75 \mathrm{mg} \mathrm{L}^{-1}\right)$ were much higher than DOC concentrations $\left(6.57 \pm 2.24 \mathrm{mg} \mathrm{L}^{-1}\right)$. DIC and DOC fluxes were 3.95 and $0.94 \mathrm{~g} \mathrm{C} \mathrm{m}^{-2} \mathrm{yr}^{-1}$, respectively. DIC concentrations increased from initial thaw (May) to freeze period (October), while DOC concentrations remained relatively steady. Daily dissolved carbon concentrations were more closely correlated with baseflow than that with total runoff. Spatially, average DIC and DOC concentrations were positively correlated with vegetation coverage but negatively correlated with bare land coverage. DIC concentrations increased with the thawed and frozen depths due to increased soil interflow, more thaw-released carbon, more groundwater contribution, and possibly more carbonate weathering by soil $\mathrm{CO}_{2}$ formed carbonic acid. The DIC and DOC fluxes increased with thawed depth and decreased with frozen layer thickness. The seasonality of riverine dissolved carbon export was highly dependent on active layer thawing and freezing processes, which highlights the importance of changing permafrost for riverine carbon export. Future warming in the QTP permafrost region may alter the quantity and mechanisms of riverine carbon export. 
1 Importance of active layer freeze-thaw cycles on the riverine

2 dissolved carbon export on the Qinghai-Tibet Plateau permafrost

4 Chunlin Song ${ }^{1,2}$, Genxu Wang*1, Tianxu $\mathrm{Mao}^{3}$, Xiaopeng Chen ${ }^{4}$, Kewei Huang1, 2 , Xiangyang

$6{ }^{1}$ Institute of Mountain Hazards and Environment, Chinese Academy of Sciences, Chengdu

7 610041, People's Republic of China

8 2University of Chinese Academy of Sciences, Beijing 100049, People's Republic of China

9 3Guizhou University, Guiyang 550025, People's Republic of China

10 4Shanxi Agricultural University, Jinzhong 030801, People's Republic of China

$11 *$ Corresponding author: Genxu Wang (Email: wanggx@imde.ac.cn, phone: +86 28 85233420,

12 fax: +862885222258$)$. 


\section{Abstract}

The Qinghai-Tibet Plateau (QTP) is experiencing severe permafrost degradation, which

29 can affect the hydrological and biogeochemical processes. Yet how the permafrost change

30 affects riverine carbon export remains uncertain. Here we investigated the seasonal variations of

31 dissolved inorganic and organic carbon (DIC and DOC) during flow seasons in a watershed

32 located in the central QTP permafrost region. The results showed that riverine DIC

33 concentrations $\left(27.81 \pm 9.75 \mathrm{mg} \mathrm{L}^{-1}\right)$ were much higher than DOC concentrations $(6.57 \pm 2.24$

$34 \mathrm{mg} \mathrm{L}^{-1}$ ). DIC and DOC fluxes were 3.95 and $0.94 \mathrm{~g} \mathrm{C} \mathrm{m}^{-2} \mathrm{yr}^{-1}$, respectively. DIC concentrations

35 increased from initial thaw (May) to freeze period (October), while DOC concentrations

36 remained relatively steady. Daily dissolved carbon concentrations were more closely correlated

37 with baseflow than that with total runoff. Spatially, average DIC and DOC concentrations were

38 positively correlated with vegetation coverage but negatively correlated with bare land coverage.

39 DIC concentrations increased with the thawed and frozen depths due to increased soil interflow,

40 more thaw-released carbon, more groundwater contribution, and possibly more carbonate

41 weathering by soil $\mathrm{CO}_{2}$ formed carbonic acid. The DIC and DOC fluxes increased with thawed

42 depth and decreased with frozen layer thickness. The seasonality of riverine dissolved carbon

43 export was highly dependent on active layer thawing and freezing processes, which highlights

44 the importance of changing permafrost for riverine carbon export. Future warming in the QTP

45 permafrost region may alter the quantity and mechanisms of riverine carbon export. 


\section{1. Introduction}

48 Understanding the role of permafrost in the global carbon cycle is becoming increasingly

49 important since climate warming and permafrost degradation can significantly mobilize the

50 permafrost carbon pool. Permafrost carbon stock is more than twice the size of the entire

51 atmospheric carbon pool, which becomes subject to enhanced biogeochemical cycling upon

52 permafrost warming and degradation (Schuur et al., 2008; 2015; Zimov et al., 2006). Permafrost

53 soil can release and process carbon from land to aquatic system or atmosphere when permafrost

54 degrades (Frey and McClelland, 2009; Schuur et al., 2008). Thawing permafrost and deepening

55 active layer (the soil layer above the permafrost that thaws during the summer and refreezes

56 during the winter) can strongly affect the catchment hydrology due to increased soil filtration,

57 deeper flow path, increased retention time, and changed soil adsorptive capacity (Frey and

58 McClelland, 2009; Kawahigashi et al., 2004; Walvoord and Kurylyk, 2016; Wang et al., 2009).

59 These response of hydrological changes to permafrost degradation are also expected to change

60 the patterns of riverine carbon export (Frey and McClelland, 2009), which is not only a major

61 component of carbon cycle (Cole et al., 2007), but also an indicator of the responses of adjacent

62 terrestrial ecosystems to environmental change (Spencer et al., 2015).

63 Riverine carbon export is closely coupled with watershed hydrology (Hartmann, 2009;

64 McClelland et al., 2016; Raymond et al., 2007; Raymond and Oh, 2007; Vihermaa et al., 2016).

65 Other factors including soil carbon, vegetation, climate change, and human activities were also 
considered to be important regulators on riverine carbon export (Hope et al., 1994; Lepistö et al.,

67 2014; Raymond et al., 2007; 2008). Permafrost distribution and change have important impacts

68 on carbon production, cycling and transport by rivers and streams (Frey and McClelland, 2009;

69 Olefeldt and Roulet, 2014; Tank et al., 2012a; Vonk et al., 2015a). In permafrost regions, the

70 lateral carbon loss that accompanies water flow in permafrost regions is highly sensitive to

71 permafrost conditions (Frey and McClelland, 2009). The deepening active layer could increase

72 DOC concentration and flux since more available organic material (Petrone et al., 2006;

73 Raymond et al., 2007). Increased pathway and longer travel time due to active layer deepening

74 could have important effects on dissolved carbon process and transport (Frampton and Destouni,

75 2015). Thawing of active layer could result in the decrease of DOC and increase of DIC due to

76 DOC mineralization and respiration (Drake et al., 2015; Striegl et al., 2005; 2007). Subsurface

77 flow pathway and groundwater change due to deepening active layer may result in riverine

78 carbon dynamics (Walvoord and Striegl, 2007). While these studies provided valuable

79 information to understand the permafrost role on riverine carbon export, knowledge about how

80 river dissolved carbon export is affected by the seasonal change of active layer in continuous

81 permafrost is lacking. Thaw and freeze depth change of active layer are associated with the

82 change of subsurface water storage, flow path and residence time (Tetzlaff et al., 2015;

83 Walvoord and Kurylyk, 2016). The seasonal change of the soil active layer thaw depth can

84 expose organic layers and mineral components of the soil profile to subsurface flow in different

85 magnitude, which are expected to affect the riverine carbon export. 
As the largest low-middle latitude permafrost region in the world, the Qinghai-Tibet Plateau

87 (QTP) is covered by a permafrost area of $1,060,000 \mathrm{~km}^{2}$ (Zou et al., 2017). The permafrost of the

88 QTP highland is warmer than Arctic permafrost and is considered to be more sensitive to

89 climatic warming than high-latitude permafrost (Cheng and $\mathrm{Wu}, 2007)$. The QTP permafrost

90 stores approximately $12.72 \mathrm{Pg} \mathrm{C}$ of soil organic carbon (Zhao et al., 2018) and 15.19 Pg C of soil

91 inorganic carbon in top 1 meter soil (Yang et al., 2010), which has the potential to be quickly

92 released from the deepening active layer to fluvial systems under climate warming scenarios

93 (Frey, 2005; Harden et al., 2012). Many permafrost riverine carbon studies focused on the boreal

94 and Arctic region, but the warmer QTP permafrost has been significantly underrepresented due

95 to a dearth of data. A previous study at northern QTP found that DOC concentration decreased as

96 thaw depth increased (Mu et al., 2017). While it is unknown about the DIC exports changes with

97 the freeze-thaw cycles of active layer. It has been documented that active layer freeze-thaw

98 cycles can significantly affect the seasonal runoff components and runoff generation processes

99 (Wang et al., 2009; 2017). We hypothesized that the quantity of riverine carbon export might be

100 ultimately affected by the active layer seasonal thaw and freeze processes for permafrost

101 underlain rivers. To address these knowledge gaps and test the hypothesis, we conducted field

102 investigations in a permafrost watershed of the QTP in 2014 and 2016 non-frozen seasons (May

103 to October). A particular emphasis of our study was on the dissolved carbon export in thawing

104 and freezing periods. In this study, we (1) characterized the spatiotemporal variations of riverine 
105 DIC and DOC concentrations, fluxes and the influencing factors and (2) elucidated the impacts

106 of active layer freeze-thaw cycles on riverine carbon export in the permafrost basin of QTP.

108 2. Methods

109

\subsection{Study Area}

110 This study was conducted in five catchments located in the Fenghuo Mountain region of the

111 QTP, which is covered by continuous permafrost (Figure 1). Table 1 shows the characteristics of

112 the catchments in detail. Catchment 2 to 5 were nested in Catchment 1 . The five catchments

113 constitute an entire watershed, Zuomaokong watershed, which is a tributary of the Tongtian

114 River that represents the headwaters of the Yangtze River. The total watershed area is $117.0 \mathrm{~km}^{2}$,

115 and the elevation of the watershed ranges from 4,720 to 5,392 $\mathrm{m}$ above sea level.

116 The study area is characterized by a cold and dry continental alpine climate. The mean

117 annual air temperature is $-5.2^{\circ} \mathrm{C}$, and the mean annual precipitation is $328.9 \mathrm{~mm}$. The highest

118 temperature (averagely $11.6^{\circ} \mathrm{C}$ ) in each year occurs in July or August, and the monthly mean air

119 temperature is above $0{ }^{\circ} \mathrm{C}$ from May to September. The relative humidity of the air ranges from

$12017 \%$ to $96 \%$ in the winter and summer, respectively. Precipitation events that occur from June to

121 September account for $85 \%$ of the total annual rainfall amount, and peak precipitation occurs in

122 July or August. During the freezing season from November to the following April, the total

123 precipitation (snowfall) is usually less than $21 \mathrm{~mm}$ (Song et al., 2017). The snow cover during 
124 the winter season is sporadic and thin, thus, snowmelt events rarely occur during the spring thaw

125 period (Wang et al., 2017).

126 Permafrost depths of the study area vary from 80 to $120 \mathrm{~m}$, and active layer depths range

127 from 1.3 to $2.5 \mathrm{~m}$ (Wu and Liu, 2004). The soil types in the study area are primarily classified as

128 Mattic-Gelic Cambisols (alpine meadow soil) (Wang et al., 2009). The vegetation within the

129 study area is dominated by alpine meadow (70\% in our study watershed) and alpine swamp

130 meadow, which are the most widespread types of vegetation across the QTP permafrost region.

131 The dominant plant species are sedges Kobresia pygmaea and Kobresia humilis (Figure S1).

132 Catchment 5 has the highest vegetation coverage $(57.3 \%)$, whereas catchment 2 has the lowest

133 vegetation coverage (32.3\%). Livestock grazing pressure in the study area is light.

134 The frozen season usually begins in October and ends in the following April. During the

135 frozen season, the river channel contains no open liquid water for sampling. The annual runoff

136 processes out of the frozen season have two flooding periods and two dry periods. These periods

137 include a summer flooding period that starts in July followed by a slight recession in early

138 August, an autumn flooding period in September with baseflow recession from late September to

139 October (Wang et al., 2011).

$140 \quad 2.2$ Field Observations

141 At the outlet of the entire watershed (catchment 1), flow depths were recorded continuously

142 using a U20 HOBO Water Level Logger (MicroDAQ, USA) at a one-hour interval (0.021 m

143 resolution). The stream velocity was measured using an FP101 Digital Water Velocity Meter 
144 (GLOBAL WATER, USA, $0.03 \mathrm{~m} \mathrm{~s}^{-1}$ resolution). We used the widely used velocity-area method

145 to calculate river discharge in this study. Soil temperature and moisture of 10 sites at depths of

$1460.05,0.2,0.5,1$, and $1.6 \mathrm{~m}$ were measured using temperature and moisture sensors (5TM,

147 Decagon Devices, USA) installed inside the catchment 3 (Figure 1), and the measurements were

148 recorded by data loggers (EM50, Decagon Devices, USA). Soil moisture and temperature were

149 measured simultaneously at 30-min intervals. The daily average soil moisture and temperature

150 data were processed in $\mathrm{R}$ (version 3.3.2), using the "xts" package. The thawed depth during the

151 thawing seasons and the frozen depth during the frozen seasons of the soil active layer (Figure

152 S2 and Figure S3) were determined based on the daily soil temperature (Frauenfeld et al., 2004).

153 We used daily soil temperature measurements at different depths to interpolate the depth of $0^{\circ} \mathrm{C}$

154 isotherm depth. Then the $0^{\circ} \mathrm{C}$ isotherm depths were used to determine thaw and freeze depth.

155 Daily mean soil temperature and moisture were displayed in Figure S4. Meteorological data,

156 including precipitation and air temperature, were collected at the meteorological station located

157 in the Zuomaokong watershed.

\section{2.3 Sample Collection and Analyses}

159 We collected stream water, rainwater and groundwater samples for DOC and DIC analyses.

160 Stream water samples were collected at the outlet of the five catchments from May to October in

1612014 and 2016. We sampled about weekly in 2014 and daily in 2016 thaw and freeze seasons.

162 Sampling work was conducted in the middle of the day. Stream water samples were collected at

163 approximately half depth from the water surface to the river bed and center of the transects at the 
164 outlets of the sub-catchments (Figure 1). Rainwater samples were collected near the

165 meteorological station after each day of rain and was assumed to represent the entire watershed

166 precipitation. Groundwater samples were collected in three groundwater observation wells $(\sim 2 \mathrm{~m}$

167 depth below ground, Figure 1) inside the watershed at a three-day interval in 2016. Fresh stream

168 water samples were filtered by vacuum filtration method immediately after sampling through

$1690.45 \mu \mathrm{m}$ pore size glass fiber filters (Shanghai Xinya, China). After filtration, $100 \mathrm{ml}$ of each

170 water sample were poured into pre-rinsed high-density polyethylene bottles with tight-fitting

171 caps and then immediately stored under frozen and dark conditions. The samples were kept

172 frozen before the analysis. We used an Elementar Vario TOC Select Analyzer (Elementar,

173 Germany) to analyze the DOC, DIC, and total dissolved nitrogen (TN) concentrations of the

174 water samples within one week after sampling. Results of triple injections of indicated the

175 analytical precision $<3 \%$. Base cations $\left(\mathrm{Na}^{+}, \mathrm{Mg}^{2+}, \mathrm{K}^{+}, \mathrm{Ca}^{2+}\right)$ from river water samples during

1762014 were analyzed with ICS-90 Ion Chromatography System (Dionex, USA).

\section{$177 \quad 2.4$ Calculations and Statistics}

178 We combined dissolved carbon measurements and continuous discharge data and used the

179 USGS load estimator (LOADEST) program (Runkel et al., 2004) to derive fluxes of DIC and

180 DOC of our study watershed. LOADEST uses daily flow and carbon concentration data to

181 establish relationships between flow and concentration and applies these relationships to the

182 complete daily discharge record and then derive flux estimates. LOADEST centers the discharge

183 and dissolved carbon concentration data to eliminate multicollinearity and selects one of nine 
184 predefined regression models to fit the data, based on the Akaike Information Criterion and

185 Schwarz Posterior Probability Criteria. This method has been widely used in the Arctic river flux

186 calculation (Tank et al., 2012; Raymond et al., 2007). In our study, the model 9 was selected by

187 the LOADEST for DIC and DOC flux estimation:

188

$\ln ($ flux $)=\mathrm{a}_{0}+\mathrm{a}_{1} \ln \mathrm{Q}+\mathrm{a}_{2} \ln \mathrm{Q}^{2}+\mathrm{a}_{3} \operatorname{Sin}(2 \pi$ dtime $)+\mathrm{a}_{4} \operatorname{Cos}(2 \pi$ dtime $)+\mathrm{a}_{5} \mathrm{dtime}+\mathrm{a}_{6}$ dtime ${ }^{2}$

189 where flux is provided in $\mathrm{kg} / \mathrm{d}, \mathrm{Q}$ is river discharge $\left(\mathrm{ft}^{3} / \mathrm{s}\right), \ln \mathrm{Q}$ equals $\ln ($ streamflow) minus

190 center of $\ln$ (streamflow), dtime equals decimal time minus center of decimal time, other

191 parameters (i.e., $\mathrm{a}_{0}, \mathrm{a}_{1}, \mathrm{a}_{2}, \mathrm{a}_{3}, \mathrm{a}_{4}, \mathrm{a}_{5}, \mathrm{a}_{6}$ ) are shown in Table 2 . LOADEST produces daily,

192 monthly and annually flux values using maximum likelihood estimation (MLE), adjusted

193 maximum likelihood estimation (AMLE), and least absolute deviation (LAD) statistical

194 approaches. All three output types provided similar results, the AMLE results were used in this

195 study. LOADEST models explained large variability of DIC and DOC, with R-squared values of

1960.9836 and 0.9794 for DIC and DOC, respectively.

197 Baseflow is usually related to subsurface flow and groundwater flow. It is necessary to test

198 the relations between baseflow and riverine carbon since permafrost degradation could enhance

199 soil drainage and recharge, suprapermafrost flow, groundwater-surface water exchange, sub-

200 permafrost flow, and baseflow (Walvoord and Kurylyk, 2016). The full observation of daily river

201 runoff during our study period allows us to use the digital filter method (Lyne and Hollick, 1979)

202 for baseflow separation. To be specific, we generated daily baseflow data in 2014 and 2016 of 
203 the catchment 1 with a web-based hydrograph tool (WHAT), which was built on the BFLOW

204 and Eckhardt filter modules (Lim et al., 2005).

205 Pearson's correlation analysis was performed to determine potential relationships between

206 hydrological and surface meteorological factors and dissolved carbon concentrations. The

207 correlation result was illustrated as a correlation matrix, which displayed Pearson's correlation

208 coefficients $\left(r_{p}\right)$ with significance levels and scaled kernel regression smoothing lines. Linear

209 correlation analyses were performed to assess the impact of spatial difference and thaw/freeze

210 depths on DIC and DOC concentrations. Since catchment 3 has the most intense observations of

211 active layer thaw, we use the data from catchment 3 to analysis the impact of freeze and thaw

212 depth on dissolved carbon export.

213

214 3. Results

215 3.1 Temporal and Spatial Variations of Dissolved Carbon

216 The DIC and DOC concentrations at the outlet of the Zuomaokong watershed displayed

217 different fluctuation patterns from May to October (Figure $2 \mathrm{a}$ and $2 \mathrm{~b}$ ). The DIC concentrations

218 showed larger fluctuations than those of DOC from May to October in both 2014 and 2016. The

219 coefficients of variation (CVs) of DIC in 2014 and 2016 were 0.39 and 0.19 , while the CVs of

220 DOC in 2014 and 2016 were 0.22 and 0.18, respectively. The DIC concentrations ranged from

2218.15 to $30.9 \mathrm{mg} \mathrm{L}^{-1}$ and 21.58 to $47.5 \mathrm{mg} \mathrm{L}^{-1}$ in 2014 and 2016, respectively. The DOC

222 concentrations during 2014 and 2016 ranged from 2.33 to $6.38 \mathrm{mg} \mathrm{L}^{-1}$ and 4.99 to $13.79 \mathrm{mg} \mathrm{L}^{-1}$, 
223 respectively. Large variations of dissolved carbon concentrations appeared both seasonally and

224 annually. Generally, the DIC concentrations increased with Julian day during the open-water

225 seasons (Figure 2, slopes of trend lines are 0.11 and 0.09 for 2014 and 2016), while the DOC

226 concentrations were relatively steady. Similar patterns were also found in other 4 sub-catchments

227 (Figure S6).

228 Seasonal variations of the dissolved carbon fluxes from the entire watershed were high in

2292014 and 2016 (Figure 3). The highest DIC and DOC fluxes (DICF and DOCF) occurred in

230 September, whereas the lowest DICF and DOCF occurred in May. Not surprisingly, the DICF

231 and DOCF were closely related to river discharge since fluxes were calculated as the function of

232 concentration and discharge. The largest runoff depths and carbon fluxes appeared

233 simultaneously in September. However, the month with the highest precipitation did not have the

234 highest carbon flux. The fluvial DIC fluxes were $2.76 \mathrm{~g} \mathrm{~m}^{-2} \mathrm{yr}^{-1}$ in 2014 and $5.14 \mathrm{~g} \mathrm{~m}^{-2} \mathrm{yr}^{-1}$ in

235 2016, whereas the DOC fluxes were $0.61 \mathrm{~g} \mathrm{~m}^{-2} \mathrm{yr}^{-1}$ in 2014 and $1.27 \mathrm{~g} \mathrm{~m}^{-2} \mathrm{yr}^{-1}$ in 2016 . The

236 average riverine DIC and DOC fluxes were 3.95 and $0.94 \mathrm{~g} \mathrm{~m}^{-2} \mathrm{yr}^{-1}$, respectively.

237 The average DIC concentration was markedly higher than the average DOC concentration

238 at the watershed outlet and in all of the sub-catchments (Table 3), which demonstrated that DIC

239 was the dominant form of dissolved carbon export in QTP permafrost rivers. In the meantime,

240 dissolved carbon concentrations showed spatial differences among the sub-catchments. The

241 mean DIC and DOC concentrations of the entire watershed measured the outlet (catchment 1)

242 were $27.81 \pm 9.75 \mathrm{mg} \mathrm{L}^{-1}$ and $6.57 \pm 2.24 \mathrm{mg} \mathrm{L}^{-1}$, respectively. Catchment 4 had the highest 
243 mean DIC and DOC concentrations, whereas catchment 3 displayed the lowest DIC

244 concentration, and catchment 2 displayed the lowest DOC concentration (Table 3).

245 Additionally, the groundwater samples had DIC and DOC concentrations that were nearly

246 double those of the stream water, which were $59.28 \pm 16.58 \mathrm{mg} \mathrm{L}^{-1}$ and $11.59 \pm 2.53 \mathrm{mg} \mathrm{L}^{-1}$,

247 respectively. But DIC and DOC concentrations of the rainwater were much lower $(3.08 \pm 1.93$

248 and $2.66 \pm 1.93 \mathrm{mg} \mathrm{L}^{-1}$ for DIC and DOC, respectively) than stream water.

\section{3.2 Factors Influencing DIC and DOC: From Time to Space}

The correlations between the time series of hydrological and meteorological variables and

DIC and DOC concentrations in catchment 1 showed that river runoff was slightly correlated

252

with the DIC and DOC concentrations, with Pearson's correlation coefficient $\left(\mathrm{r}_{\mathrm{p}}\right)$ of 0.30 and

0.32, respectively. Interestingly, DIC and DOC concentrations showed closer correlations with

the baseflow ( $r_{p}=0.67$ and 0.54 , respectively) than total river runoff. Precipitation and air

temperature showed weak correlations with DIC and DOC concentrations. Meanwhile, the DIC

and DOC concentrations were closely correlated to each other, with an $r_{p}$ of 0.84 (Figure 4),

indicating close associations between DIC and DOC.

The different characteristics of the sub-catchments allow us to analyze the potential factors

affecting the spatial variations of dissolved carbon concentrations with correlation analyses. The

results showed that the dissolved carbon concentrations were closely associated with the land

262 (correlation coefficient $\left(r_{p}\right)=0.82$ and 0.91 , respectively), but weakly correlated with wetland 
$263 \operatorname{cover}\left(r_{p}=0.21\right.$ and 0.32 , respectively) within the five catchments (Figure 5). The bare land

264 coverage showed negative relationships with DIC and DOC ( $r_{p}=-0.88$ and -0.78 , respectively).

265 The dissolved carbon concentrations decreased as mean elevation increased since vegetation

266 cover decreased and bare land cover increased in higher elevation catchments. Catchment size

267 showed a limited impact on the dissolved carbon concentrations in our study watershed.

\section{3.3 Effects of Active Layer Freeze-Thaw Cycles}

269 Our results revealed that the thawing process had a significant impact on dissolved carbon

270 concentrations and fluxes. The linear relationships between the DIC concentrations and the

271 thawed depths during the 2016 thawing periods were statistically significant $\left(\mathrm{R}^{2}=0.289, \mathrm{p}=\right.$

2720.007 , Figures 6a). As the active layer thawed at greater depths, the DIC concentrations in the

273 river increased. The relationship between the DOC concentration and the thawed depth was

274 weaker but also statistically significant with positive relations $\left(R^{2}=0.162, p=0.05\right.$, Figures $\left.6 c\right)$.

275 In this period, the DIC and DOC concentration was $19.47 \mathrm{mg} / \mathrm{L}$ and $5.56 \mathrm{mg} / \mathrm{L}$, respectively. The

276 DIC and DOC fluxes showed strong positive relationships with the thawed depth. The DIC and

277 DOC fluxes increased as the thawed depth increased in both 2014 and 2016 thawing seasons.

278 The $\mathrm{R}^{2}$ values and $p$-values of these relationships were in the range of $0.42-0.49$ and $<0.001$,

279 respectively.

280 As temperature decreased in October, the soil active layer started to freeze two-sided, from

281 the surface and the bottom of the soil active layer (Woo, 2012). The results showed that the DIC

282 and DOC concentrations increased as the frozen depth increased during the 2016 freezing period 
283 (Figure 7a and 7c). In this period, the DIC and DOC concentration was $35.91 \mathrm{mg} / \mathrm{L}$ and 7.28

$284 \mathrm{mg} / \mathrm{L}$, respectively. As the freezing process proceeded and the frozen depth became deeper, the

285 DIC and DOC fluxes decreased $\left(\mathrm{R}^{2}=0.5546\right.$ and $0.5147, \mathrm{p}<0.001$ and $\mathrm{p}<0.001$, for DIC

286 fluxes and DOC fluxes, respectively).

287

288 4. Discussion

289 4.1 Patterns in Stream Water DIC and DOC

290 The mean DOC concentration in our study area was much lower than many comparable

291 small Arctic streams, where these rivers showed tens to hundreds milligram per liter of DOC

292 concentrations (Frey et al., 2016; Tank et al., 2012a; Vonk et al., 2013). The values of soil

293 organic carbon (SOC) density measured in Tibetan Plateau alpine meadows $\left(9.05 \mathrm{~kg} \mathrm{C} \mathrm{m}^{-2}\right.$ in 0 -

$294100 \mathrm{~cm}$ depth) (Yang et al., 2008) were much lower than those measured in Arctic permafrost

295 regions (32.2-69.6 $\mathrm{kg} \mathrm{C} \mathrm{m}^{-2}$ ) (Tarnocai et al., 2009), which may explain the low DOC

296 concentrations compared to most Arctic rivers. The rapid utilization of DOC after thaw (Drake et

297 al., 2015; Vonk et al., 2015a) may also result in the low DOC in permafrost river water. The

298 mean DIC concentrations of stream water within our field area were higher than those of Arctic

299 permafrost rivers (Prokushkin et al., 2011; Tank et al., 2012b). One possible reason may be the

300 high soil inorganic carbon density (11.87 $\mathrm{kg} \mathrm{C} \mathrm{m}^{-2}$ in 0-100 $\mathrm{cm}$ depth) in the QTP alpine

301 meadow (Yang et al., 2010) which produce high DIC concentrations. Also, the large proportion

302 of subsurface interflow, which is averagely $25.2 \%$ of total runoff (Wang et al., 2009), could 
303 possibly introduce much soil carbon into the river channels. The dissolved carbon concentrations

304 were higher than non-permafrost rivers (Ran et al., 2013; Vihermaa et al., 2016). The relatively

305 high total dissolved carbon concentrations at our site indicated that the active layer in such high-

306 elevation permafrost is a hotspot for promoting dissolved carbon loss.

307 DIC was the dominant component of dissolved carbon exported to river water. The main

308 reason for the higher DIC than DOC may be that the soil inorganic carbon (SIC) stock is as large

309 as 2.1 times of SOC stock in the Tibetan plateau ecosystem (Yang et al., 2010). The dominant

310 throughflow leached inorganic material from the deep soil layer, which has higher SIC density

311 than the upper soil layer (Yang et al., 2010). According to the cation measurements of our site

312 (Figure S5), the dominant cations are $\mathrm{Ca}$ and $\mathrm{Na}+\mathrm{K}\left(\mathrm{Na}^{+}>\mathrm{Ca}^{2+}>\mathrm{Mg}^{2+}>\mathrm{K}^{+}\right)$, which indicate an

313 important role of mineral weathering and evaporates salt dissolution in the study watershed. A

314 previous study showed widespread carbonate weathering processes $\left(\mathrm{CaCO}_{3}+\mathrm{H}_{2} \mathrm{O}+\mathrm{CO}_{2} \rightarrow\right.$

$315 \mathrm{Ca}^{2+}+2 \mathrm{HCO}_{3}^{-}$) across the Yangtze River source region (Wu et al., 2008), which can consume

$316 \mathrm{CO}_{2}$ and produce DIC. Besides, the average DOC and total dissolved nitrogen ratio (DOC/TDN,

$317 \mathrm{C} / \mathrm{N}$ ) in our watershed were $\sim 4.32$ (Table $\mathrm{S} 1$ ), which is much lower than the global average $\mathrm{C} / \mathrm{N}$

318 value of 22.1 (Meybeck, 1982). Low C/N ratio implies an abundant supply of nitrogen that could

319 enhance the biological metabolism and DOC microbe decomposition (Wiegner et al., 2006).

320 Another evidence is that a previous study at this site showed considerable amounts of old water

321 (which is dominant in groundwater) constituted the stream flow (Song et al., 2017). The long

322 retention time of old water within the basin could increase the contact of DOC to subsurface 
323 microbes, which may promote the decomposition of DOC in the active layer (Lyon et al., 2010;

324 Striegl et al., 2005; 2012). The higher DIC and lower DOC concentrations also indicated large

325 proportions of subsurface flow and deeper groundwater recharge to streamflow in permafrost

326 watersheds (Giesler et al., 2014; Walvoord and Striegl, 2007). High DIC and low DOC were also

327 found in Arctic rivers including Tanana and Porcupine rivers (Striegl et al., 2007), Yenisey River

328 (Prokushkin et al., 2011), and the Yukon River (Striegl et al., 2005) due to enhanced organic

329 carbon mineralization.

330 There were increasing trends of DIC concentrations during the thawed periods of 2014 and

331 2016, but the DOC concentration remained relatively steady (Figure 2). The DIC:DOC ratios

332 increased during the thawed periods of 2014 and 2016 (Figure S7). Walwoord and Striegl (2007)

333 also found an increasing trend of the groundwater contribution and adding of DIC to streamflow

334 in the Yukon River basin. The similar pattern of linear increase through the year in DIC was also

335 found in Sweden rivers (Giesler et al., 2014). A possible explanation is that both DIC

336 concentration and DOC concentration increased because the groundwater flow and flow path

337 lengths increased as thawing progressed to greater depths (Vonk et al., 2015a), but the SIC

338 density increased with soil layer depth (Zhang et al., 2016), which could result in higher DIC

339 export when active layer thaw. The increased DIC concentration with Julian day in our study

340 indicated deeper thawed depth and larger groundwater contribution proportion to total runoff

341 from spring to autumn (Wang et al., 2017). In the autumn, the groundwater discharge contributed

342 more than $75 \%$ of the total river runoff (Wang et al., 2017), which brought both high DIC 
343 concentration and DOC concentration to stream water. Future degradation of permafrost may

344 lead to groundwater-dominated hydrologic systems among permafrost regions (Frey and

345 McClelland, 2009), which will cause more carbon export through groundwater.

346 The correlation relationships of DIC and DOC concentration and discharge were limited

347 compared to those of previous studies (Li and Bush, 2015; Song et al., 2016; Tank et al., 2012b;

348 Tian et al., 2015). The dilution of dissolved carbon during high flow periods and the large

349 proportion of groundwater recharge during low flow periods may weaken the relationship

350 between dissolved carbon concentrations and discharge (Tank et al., 2012b). Baseflow was more

351 closely related to dissolved carbon concentrations than total runoff. Baseflow contains shallow

352 subsurface flow and groundwater flow, which could directly leach soil carbon to water channel

353 when active layer thaw. As a result, more riverine carbon originated from the baseflow rather

354 than the overland flow. The role of baseflow for permafrost riverine carbon export will become

355 increasingly important in a warming climate. As permafrost degrades, enhanced baseflow and

356 subsurface hydrological activities (Frey et al., 2007; Walvoord and Kurylyk, 2016) could bring

357 more permafrost carbon to aquatic systems. Our results highlight the importance of dissolved

358 carbon supply from baseflow to river flow.

359 The mean river runoff in 2016 was $20 \%$ larger than $2014\left(1.27 \mathrm{~m}^{3} / \mathrm{s}\right.$ versus $1.06 \mathrm{~m}^{3} / \mathrm{s}$ of

360 daily mean discharge). This may explain the dissolved carbon concentrations and fluxes in 2016

361 were larger than those of 2014. The carbon fluxes results of QTP differed from measurements

362 taken in the Yenisey basin, where carbon export was dominated by DOC (Prokushkin et al., 
363 2011). The DIC flux constituted $81 \%$ of the total dissolved carbon flux, and this proportion was

364 close to Yukon rivers at Eagle (80\%) and Pilot Station (75\%) (Striegl et al., 2007). In 2014 and

3652016 , the total riverine dissolved carbon exported from the Zuomaokong watershed were 431

366 and $818 \mathrm{t} \mathrm{C} \mathrm{yr}^{-1}$, respectively. The higher dissolved carbon flux in 2016 was due to the higher

367 dissolved carbon concentrations and larger river runoff in 2016.

368 The spatial variations in the dissolved carbon concentrations of the five catchments showed

369 both the DIC and DOC concentrations are higher in catchments with high vegetation coverage

370 (Vc) values (Figure 5). The catchments with larger Vc will have higher ecosystem productivity

371 and soil organic carbon density (Wang et al., 2002; 2008) and thus contain more abundant

372 sources for riverine carbon. Previous studies at this site showed that the higher the vegetation

373 coverage is, the higher the soil temperature during the thawing and freezing period will be

374 (Wang et al., 2012). High vegetation covers also led to earlier thaw-rise times (Wang et al.,

375 2012). Thus, the mean dissolved carbon concentration increased because the higher soil

376 temperatures and earlier thaw-rise times make carbon from the thawed soil available to the water

377 flow. The coupling between vegetation and soil thermal conditions caused the differences in

378 dissolved carbon concentrations under different vegetation cover. Conversely, catchment with

379 larger bare land cover could have lower soil carbon density and later thaw-rise time, which

380 decrease the dissolved carbon concentrations. Dissolved carbon concentrations decreased with

381 the mean elevation of the catchment may be due to the high-elevation catchments have greater

382 areas of bare land and snow cover. Wetland distribution can enhance the production of organic 
383 carbon (Huntington and Aiken, 2013) and have high DOC concentration in the soil profile (Chen

384 et al., 2017a), which explained the positive correlation between DOC and wetland coverage.

\section{4.2 Active Layer Dynamics and Riverine Carbon Export}

386 During the thawing period, the DIC concentration increased as the thawing processes

progressed (Figure 6). Thawed permafrost could enhance the connection between water and soil

horizons and increase carbon concentrations (Vonk et al., 2015a). During the thawing period in

spring, as air and soil temperatures rose, the surface soil layer started to thaw. The dominant

runoff component in this period was subsurface interflow (Wang et al., 2017). According to the

391

previous investigation in the QTP grassland, SIC density at different soil depths showed a pattern

of top $30 \mathrm{~cm}<$ top $50 \mathrm{~cm}<$ top $100 \mathrm{~cm}$ (Yang et al., 2010). Thus, when the active layer

temperature, the greater thickness of the active layer (Wu and Zhang, 2010), which could result

in more soil interflow and deeper flow pathways. As soil thaw depth increased, the leaching

potential of dissolved carbon from soil also increased. Besides, the soil respired $\mathrm{CO}_{2}$ also rise as

active layer thaw (Chen et al., 2017). More soil $\mathrm{CO}_{2}$ and soil water can form carbonic acid,

which may enhance the mineral weathering and produce more DIC (Zolkos et al., 2018).

Consequently, more DIC leached from the active layer to the water flow, and the DIC

concentrations of river water increased.

401 Surprisingly, DOC concentrations were positively correlated with thaw depth (Figure 6c).

402 Study in a northern QTP stream found DOC concentrations negatively correlated with thaw 
403 depth due to less organic carbon source in the deeper soil layer (Mu et al., 2017). While in our

404 study area, the SOC is $27.39,33.15$ and $28.69 \mathrm{mg} / \mathrm{g}$ for $0-5 \mathrm{~cm}, 5-20 \mathrm{~cm}$, and $20-40 \mathrm{~cm}$,

405 respectively (Chen et al., 2017b), which partly explained why the riverine DOC increased with

406 thawed depth during spring thaw period. When the active layer thawed to the deeper soil layer

407 where SOC is lower (Ding et al., 2016; Mu et al., 2016; Yang et al., 2008), the groundwater

408 contribution rate increased as the thawing process proceeded (Wang et al. 2007). Therefore, the

409 increased groundwater, which contains a high concentration of DOC $(11.59 \mathrm{mg} / \mathrm{L})$, overriding

410 the potential effects of lower SOC supply in the deeper soil layer and OC decomposition (Drake

411 et al., 2015; Striegl et al., 2005; 2007). As a result, riverine DOC increased. Even so, whether

412 such pattern is widespread across QTP permafrost rivers need further study. The dissolved

413 carbon fluxes also increased with thawed depth as more river runoff and higher carbon

414 concentrations during in deep thawed period.

415 During the freezing period, the active layer displayed a pattern of two-sided freezing (Woo,

416 2012). As the air temperature decreased, the surface layer began to freeze and cool downward.

417 The frozen surface layer stopped the escape of heat from the middle layer. The bottom of the

418 active layer also started to freeze at the same time. Therefore, the middle layer was still unfrozen

419 during the early stage of the freezing process. Meanwhile, precipitation decreased rapidly during

420 the freezing period. The frozen impermeable surface and bottom layer obstructed the infiltration

421 of precipitation and groundwater to deeper layers (Wang et al., 2009). As a result, the proportion

422 of groundwater supply in river runoff increased when the frozen depth increased (Wang et al., 
423 2017). The groundwater is characterized by high dissolved carbon concentrations $\left(59.28 \mathrm{mg} \mathrm{L}^{-1}\right.$

424 of DIC and $11.59 \mathrm{mg} \mathrm{L}^{-1}$ of DOC) than the river water and precipitation (Table 3). Under these

425 circumstances, the DIC concentration and DOC concentration increase as the frozen depth

426 increases. The decrease in dissolved carbon fluxes as the frozen depth increased was because of

427 the rapidly decreased river discharge, which caused by reductions in precipitation and the

428 gradual freezing of subsurface flow. Through the above analyses, we can see that active layer

429 soil carbon exported to rivers was closely linked with thawing and freezing period as illustrated

430 in the conceptual diagram (Figure 8). Although our measurements of active layer thaw/freeze

431 depths may have uncertainties, the pattern of active layer impacts still existed in two years of

432 different meteorological and hydrological characteristics.

433 We consider the soil active layer freeze-thaw cycles to be the most important factors

434 affecting the riverine dissolved carbon export in our site for the following four reasons. First, the

435 thawing and freezing processes controlled the thaw-released soil carbon from the active layer. As

436 shown before, riverine dissolved carbon concentrations were closely related to active layer thaw

437 and freeze depth. Second, permafrost river baseflow, which closely related to riverine carbon,

438 was largely regulated by active layer thaw (Smith et al., 2007). Third, the widely distributed

439 freeze-thaw erosion in the QTP, which can affect the lateral soil carbon export, is controlled by

440 freeze-thaw cycles (Zhang et al., 2007; Wang et al., 2017). Fourth, the dissolved carbon fluxes

441 were determined by discharge volumes, while surface runoff processes were primarily controlled

442 by active layer freeze-thaw cycles rather than precipitation (Wang et al., 2009). The systematic 
443 shifts of DIC and DOC we observed during the flow season mainly reflected the seasonal change

444 of active layer.

445 The active layer was predicted to become thicker in the future warming scenario (Wu and

446 Zhang, 2010; Yang et al., 2010; Zhang et al., 2005). This prediction suggests earlier spring thaw

447 and later autumn freeze up due to the increases in the length and depth of subsurface flow paths

448 that will occur under climate warming (Frampton et al., 2011). The period during which lateral

449 carbon losses occur in each year will be extended. Increased thaw depth could possibly extend

450 the residence time of dissolved carbon in the flow path, which could affect the biodegradability

451 of DOC (Vonk et al., 2015b). It then becomes inevitable that the active layer change will change

452 the carbon export patterns. Additionally, changes in soil water content could affect the active

453 layer thermal state and the thawing and freezing processes of the soil active layer (Wang et al.,

454 2012), which may also accelerate the lateral carbon export. A warming climate and the

455 corresponding increase in the thickness of the active layer (Yang et al., 2010) may enhance this

456 carbon loss through permafrost degradation and active layer thaw, which will eventually affect

457 the regional carbon cycling.

458

459 5. Summary and Conclusions

460 In this study we showed that large amounts of terrigenous carbon were exported to rivers in

461 headwater streams of the QTP continuous permafrost region. DIC is the overwhelmingly

462 dominant form of dissolved carbon in our study watershed. The DIC flux constitutes more than 
$46380 \%$ of the total dissolved carbon flux, with $3.95 \mathrm{~g} \mathrm{C} \mathrm{m}^{-2} \mathrm{yr}^{-1}$ of DIC and $0.94 \mathrm{~g} \mathrm{C} \mathrm{m}^{-2} \mathrm{yr}^{-1} \mathrm{of}$

464 DOC fluxes. The higher DIC concentration than DOC may due to the higher SIC than SOC

465 density. Dissolved carbon concentrations were closely related to baseflow, suggesting the

466 importance of subsurface flow and groundwater supply to riverine carbon. Spatial distribution of

467 dissolved carbon was mainly differed by land cover. Seasonal changes of DIC and DOC were

468 mainly affected by freeze-thaw cycles. The river water cation data suggest carbonate weathering

469 by soil $\mathrm{CO}_{2}$ dissolution may also play a role in riverine DIC export. The active layer freeze-thaw

470 cycles played important roles in the riverine dissolved carbon export of the QTP since freeze-

471 thaw cycles controlled the thawed carbon release and catchment hydrological processes. Our

472 findings provide new insights into the carbon cycling of this region and highlight the importance

473 of soil active layer thawing and freezing processes on riverine carbon export in permafrost

474 regions. Climate warming-induced permafrost degradation may result in higher disturbance of

475 permafrost carbon and create a subsurface flow dominated hydrology system, which will lead to

476 more lateral transport of dissolved carbon to river networks and change the regional carbon

477 balance. More attention should be paid to the relationships between permafrost change and

478 riverine carbon export.

479

480 Acknowledgements

481 We thank the staffs of Fenghuo Mountain Observation Station of China Railway Northwest

482 Institute for assisting our field work. 


\section{References}

485 Chen, X., Wang, G., Zhang, T., Mao, T., Wei, D., Hu, Z., Song, C., 2017. Effects of warming

486

487

488

489

490

491

492

493

494

495

496

497

498

499

500

501

502

503

504

505

506

507

508

509

510

511

512

513

514

515

516

517

518

519

520 and nitrogen fertilization on GHG flux in the permafrost region of an alpine meadow. Atmospheric Environment 111-124. doi:10.1016/j.atmosenv.2017.03.024

Cheng, G., Wu, T., 2007. Responses of permafrost to climate change and their environmental significance, Qinghai-Tibet Plateau. Journal of Geophysical Research: Earth Surface 112, F02S03. doi:10.1029/2006JF000631

Cole, J.J., Prairie, Y.T., Caraco, N.F., McDowell, W.H., Tranvik, L.J., Striegl, R.G., Duarte, C.M., Kortelainen, P., Downing, J.A., Middelburg, J.J., Melack, J., 2007. Plumbing the global carbon cycle: Integrating inland waters into the terrestrial carbon budget. Ecosystems 10, 171-184. doi:10.1007/s10021-006-9013-8

Ding, J., Li, F., Yang, G., Chen, L., Zhang, B., Liu, L., Fang, K., Qin, S., Chen, Y., Peng, Y., Ji, C., He, H., Smith, P., Yang, Y., 2016. The permafrost carbon inventory on the Tibetan Plateau: a new evaluation using deep sediment cores. Glob Change Biol 22, 2688-2701. doi: $10.1111 / \mathrm{gcb} .13257$

Drake, T.W., Wickland, K.P., Spencer, R.G.M., McKnight, D.M., Striegl, R.G., 2015. Ancient low-molecular-weight organic acids in permafrost fuel rapid carbon dioxide production upon thaw. Proc. Natl. Acad. Sci. U.S.A. 112, 13946-13951. doi:10.1073/pnas.1511705112

Frampton, A., Destouni, G., 2015. Impact of degrading permafrost on subsurface solute transport pathways and travel times. Water Resour. Res. 51, 7680-7701. doi:10.1002/2014WR016689

Frampton, A., Painter, S., Lyon, S.W., Destouni, G., 2011. Non-isothermal, three-phase simulations of near-surface flows in a model permafrost system under seasonal variability and climate change. Journal of Hydrology 403, 352-359. doi:10.1016/j.jhydrol.2011.04.010

Frauenfeld, O.W., Zhang, T., Barry, R.G., Gilichinsky, D., 2004. Interdecadal changes in seasonal freeze and thaw depths in Russia. J. Geophys. Res. 109. doi:10.1029/2003jd004245

Frey, K.E., 2005. Amplified carbon release from vast West Siberian peatlands by 2100. Geophys. Res. Lett. 32, L09401-4. doi:10.1029/2004GL022025

Frey, K.E., McClelland, J.W., 2009. Impacts of permafrost degradation on arctic river biogeochemistry. Hydrol. Process. 23, 169-182. doi:10.1002/hyp.7196

Frey, K.E., McClelland, J.W., Holmes, R.M., Smith, L.C., 2007. Impacts of climate warming and permafrost thaw on the riverine transport of nitrogen and phosphorus to the Kara Sea. Journal of Geophysical Research: Earth Surface 112, G04S58. doi:10.1029/2006JG000369

Frey, K.E., Sobczak, W.V., Mann, P.J., 2016. Optical properties and bioavailability of dissolved organic matter along a flow-path continuum from soil pore waters to the Kolyma River mainstem, East Siberia. Biogeosciences.

Giesler, R., Lyon, S.W., Mörth, C.M., Karlsson, J., Karlsson, E.M., Jantze, E.J., Destouni, G., Humborg, C., 2014. Catchment-scale dissolved carbon concentrations and export estimates 
521

522

523

524

525

526

527

528

529

530

531

532

533

534

535

536

537

538

539

540

541

542

543

544

545

546

547

548

549

550

551

552

553

554

555

556

557

558

559

across six subarctic streams in northern Sweden. Biogeosciences 11, 525-537.

doi:10.5194/bg-11-525-2014

Harden, J.W., Koven, C.D., Ping, C.-L., Hugelius, G., David McGuire, A., Camill, P., Jorgenson, T., Kuhry, P., Michaelson, G.J., O'Donnell, J.A., Schuur, E.A.G., Tarnocai, C., Johnson, K., Grosse, G., 2012. Field information links permafrost carbon to physical vulnerabilities of thawing. Geophys. Res. Lett. 39. doi:10.1029/2012GL051958

Hartmann, J., 2009. Bicarbonate-fluxes and CO2-consumption by chemical weathering on the Japanese Archipelago - Application of a multi-lithological model framework. Chemical Geology 265, 237-271. doi:10.1016/j.chemgeo.2009.03.024

Hope, D., Billett, M.F., Cresser, M.S., 1994. A review of the export of carbon in river water: Fluxes and processes. Environmental Pollution 84, 301-324. doi:10.1016/02697491(94)90142-2

Huntington, T.G., Aiken, G.R., 2013. Export of dissolved organic carbon from the Penobscot River basin in north-central Maine. Journal of Hydrology 476, 244-256.

doi:10.1016/j.jhydrol.2012.10.039

Kawahigashi, M., KAISER, K., Kalbitz, K., Rodionov, A., Guggenberger, G., 2004. Dissolved organic matter in small streams along a gradient from discontinuous to continuous permafrost. Glob Change Biol 10, 1576-1586. doi:10.1111/j.1365-2486.2004.00827.x Lepistö, A., Futter, M.N., Kortelainen, P., 2014. Almost 50 years of monitoring shows that climate, not forestry, controls long-term organic carbon fluxes in a large boreal watershed. Glob Change Biol 20, 1225-1237. doi:10.1111/gcb.12491

Li, S., Bush, R.T., 2015. Changing fluxes of carbon and other solutes from the Mekong River. Sci. Rep. 5, 16005. doi:10.1038/srep16005

Lim, K.J., Engel, B.A., Tang, Z., Choi, J., Kim, K.S., Muthukrishnan, S., Tripathy, D., 2005. AUTOMATED WEB GIS BASED HYDROGRAPH ANALYSIS TOOL, WHAT. JAWRA Journal of the American Water Resources Association 41, 1407-1416. doi:10.1111/j.17521688.2005.tb03808.x

Lyne, V., Hollick, M., 1979. Stochastic Time-Variable Rainfall-Runoff Modeling, in:. Presented at the Hydro. and Water Resour. Symp., Perth, Australia, pp. 89-92.

Lyon, S.W., Mörth, M., Humborg, C., Giesler, R., Destouni, G., 2010. The relationship between subsurface hydrology and dissolved carbon fluxes for a sub-arctic catchment. Hydrol. Earth Syst. Sci. 14, 941-950. doi:10.5194/hess-14-941-2010

McClelland, J.W., Holmes, R.M., Peterson, B.J., Raymond, P.A., Striegl, R.G., Zhulidov, A.V., Zimov, S.A., Zimov, N., Tank, S.E., Spencer, R.G.M., Staples, R., Gurtovaya, T.Y., Griffin, C.G., 2016. Particulate organic carbon and nitrogen export from major Arctic rivers. Global Biogeochemical Cycles 30, 629-643. doi:10.1002/2015GB005351

Meybeck, M., 1982. Carbon, nitrogen, and phosphorus transport by world rivers. American Journal of Science 282, 401-450. doi:10.2475/ajs.282.4.401

Mu, C.C., Abbott, B.W., Wu, X.D., Zhao, Q., Wang, H.J., Su, H., Wang, S.F., Gao, T.G., Guo, 
560

561

562

563

564

565

566

567

568

569

570

571

572

573

574

575

576

577

578

579

580

581

582

583

584

585

586

587

588

589

590

591

592

593

594

595

596

597

598

\section{H., Peng, X.Q., Zhang, T.J., 2017. Thaw Depth Determines Dissolved Organic Carbon} Concentration and Biodegradability on the Northern Qinghai-Tibetan Plateau. Geophys. Res. Lett. 44, 9389-9399. doi:10.1002/2017GL075067

Olefeldt, D., Roulet, N.T., 2014. Permafrost conditions in peatlands regulate magnitude, timing, and chemical composition of catchment dissolved organic carbon export. Glob Change Biol 20, 3122-3136. doi:10.1111/gcb.12607

Petrone, K.C., Jones, J.B., Hinzman, L.D., Boone, R.D., 2006. Seasonal export of carbon, nitrogen, and major solutes from Alaskan catchments with discontinuous permafrost. J. Geophys. Res. 111, G02020. doi:10.1029/2005JG000055

Prokushkin, A.S., Pokrovsky, O.S., Shirokova, L.S., Korets, M.A., Viers, J., Prokushkin, S.G., Amon, R.M.W., Guggenberger, G., McDowell, W.H., 2011. Sources and the flux pattern of dissolved carbon in rivers of the Yenisey basin draining the Central Siberian Plateau.

Environmental Research Letters 6, 045212. doi:10.1088/1748-9326/6/4/045212

Ran, L.S., Lu, X.X., Sun, H.G., Han, J.T., Li, R.H., Zhang, J.M., 2013. Spatial and seasonal variability of organic carbon transport in the Yellow River, China. Journal of Hydrology 498, 76-88. doi:10.1016/j.jhydrol.2013.06.018

Raymond, P.A., McClelland, J.W., Holmes, R.M., Zhulidov, A.V., Mull, K., Peterson, B.J., Striegl, R.G., Aiken, G.R., Gurtovaya, T.Y., 2007. Flux and age of dissolved organic carbon exported to the Arctic Ocean: A carbon isotopic study of the five largest arctic rivers. Global Biogeochemical Cycles 21, GB4011. doi:10.1029/2007GB002934

Raymond, P.A., Oh, N.-H., 2007. An empirical study of climatic controls on riverine C export from three major U.S. watersheds. Global Biogeochemical Cycles 21.

doi:10.1029/2006gb002783

Raymond, P.A., Oh, N.-H., Turner, R.E., Broussard, W., 2008. Anthropogenically enhanced fluxes of water and carbon from the Mississippi River. Nature 451, 449-452.

doi:10.1038/nature06505

Runkel, R.L., Crawford, C.G., Cohn, T.A., 2004. Load Estimator (LOADEST): A FORTRAN Program for Estimating Constituent Loads in Streams and Rivers, in: U.S. Geological Survey Techniques and Methods Book. US Geological Survey, p. 69.

Schuur, E.A.G., Bockheim, J., Canadell, J.G., Euskirchen, E., Goryachkin, S.V., Hagemann, S., Kuhry, P., Lafleur, P.M., Lee, H., Mazhitova, G., Nelson, F.E., Rinke, A., Romanovsky, V.E., Shiklomanov, N., Tarnocai, C., Venevsky, S., Vogel, J.G., Zimov, S.A., 2008.

Vulnerability of Permafrost Carbon to Climate Change: Implications for the Global Carbon Cycle. BioScience 58, 701-714. doi:10.1641/B580807

Schuur, E.A.G., McGuire, A.D., Schädel, C., Grosse, G., Harden, J.W., Hayes, D.J., Hugelius, G., Koven, C.D., Kuhry, P., Lawrence, D.M., Natali, S.M., Olefeldt, D., Romanovsky, V.E., Schaefer, K., Turetsky, M.R., Treat, C.C., Vonk, J.E., 2015. Climate change and the permafrost carbon feedback. Nature 520, 171-179. doi:10.1038/nature14338

Smith, L.C., Pavelsky, T.M., MacDonald, G.M., Shiklomanov, A.I., Lammers, R.B., 2007.

Peer] reviewing PDF | (2019:04:36338:1:1:NEW 15 May 2019) 
599

600

601

602

603

604

605

606

607

608

609

610

611

612

613

614

615

616

617

618

619

620

621

622

623

624

625

626

627

628

629

630

631

632

633

634

635

636

637

Rising minimum daily flows in northern Eurasian rivers: A growing influence of groundwater in the high-latitude hydrologic cycle. J. Geophys. Res. 112, G04S47. doi:10.1029/2006JG000327

Song, C., Wang, G., Liu, G., Mao, T., Sun, X., Chen, X., 2017. Stable isotope variations of precipitation and streamflow reveal the young water fraction of a permafrost watershed. Hydrol. Process. 31, 935-947. doi:10.1002/hyp.11077

Song, C., Wang, G., Sun, X., Chang, R., Mao, T., 2016. Control factors and scale analysis of annual river water, sediments and carbon transport in China. Sci. Rep. 6, 25963. doi:10.1038/srep25963

Spencer, R.G.M., Mann, P.J., Dittmar, T., Eglinton, T.I., McIntyre, C., Holmes, R.M., Zimov, N., Stubbins, A., 2015. Detecting the signature of permafrost thaw in Arctic rivers. Geophysical Research Letters 42, 2830-2835. doi:10.1002/2015GL063498

Striegl, R.G., Aiken, G.R., Dornblaser, M.M., Raymond, P.A., Wickland, K.P., 2005. A decrease in discharge-normalized DOC export by the Yukon River during summer through autumn. Geophys. Res. Lett. 32, L21413. doi:10.1029/2005g1024413

Striegl, R.G., Dornblaser, M.M., Aiken, G.R., Wickland, K.P., Raymond, P.A., 2007. Carbon export and cycling by the Yukon, Tanana, and Porcupine rivers, Alaska, 2001-2005. Water Resour. Res. 43, W02411. doi:10.1029/2006WR005201

Striegl, R.G., Dornblaser, M.M., McDonald, C.P., Rover, J.R., Stets, E.G., 2012. Carbon dioxide and methane emissions from the Yukon River system. Global Biogeochemical Cycles 26. doi: $10.1029 / 2012 \mathrm{gb004306}$

Tank, S.E., Frey, K.E., Striegl, R.G., Raymond, P.A., Holmes, R.M., McClelland, J.W., Peterson, B.J., 2012a. Landscape-level controls on dissolved carbon flux from diverse catchments of the circumboreal. Global Biogeochemical Cycles 26, GB0E02. doi:10.1029/2012GB004299

Tank, S.E., Raymond, P.A., Striegl, R.G., McClelland, J.W., Holmes, R.M., Fiske, G.J., Peterson, B.J., 2012b. A land-to-ocean perspective on the magnitude, source and implication of DIC flux from major Arctic rivers to the Arctic Ocean. Global Biogeochemical Cycles 26, GB4018. doi:10.1029/2011GB004192

Tarnocai, C., Canadell, J.G., Schuur, E.A.G., Kuhry, P., Mazhitova, G., Zimov, S., 2009. Soil organic carbon pools in the northern circumpolar permafrost region. Global Biogeochemical Cycles 23, GB2023. doi:10.1029/2008GB003327

Tetzlaff, D., Buttle, J., Carey, S.K., McGuire, K., Laudon, H., Soulsby, C., 2015. Tracer-based assessment of flow paths, storage and runoff generation in northern catchments: a review. Hydrol. Process. 29, 3475-3490. doi:10.1002/hyp.10412

Tian, H., Ren, W., Yang, J., Tao, B., Cai, W.-J., Lohrenz, S.E., Hopkinson, C.S., Liu, M., Yang, Q., Lu, C., Zhang, B., Banger, K., Pan, S., He, R., Xue, Z., 2015. Climate extremes dominating seasonal and interannual variations in carbon export from the Mississippi River Basin. Global Biogeochemical Cycles 29, 1333-1347. doi:10.1002/2014GB005068

Peer] reviewing PDF | (2019:04:36338:1:1:NEW 15 May 2019) 
638 Vihermaa, L.E., Waldron, S., Domingues, T., Grace, J., Cosio, E.G., Limonchi, F., Hopkinson,

639

640

641

642

643

644

645

646

647

648

649

650

651

652

653

654

655

656

657

658

659

660

661

662

663

664

665

666

667

668

669

670

671

672

673

674

675

676 C., da Rocha, H.R., Gloor, E., 2016. Fluvial carbon export from a lowland Amazonian rainforest in relation to atmospheric fluxes. J. Geophys. Res. Biogeosci. 121, 3001-3018. doi:10.1002/2016JG003464

Vonk, J.E., Mann, P.J., Davydov, S., Davydova, A., Spencer, R.G.M., Schade, J., Sobczak, W.V., Zimov, N., Zimov, S., Bulygina, E., Eglinton, T.I., Holmes, R.M., 2013. High biolability of ancient permafrost carbon upon thaw. Geophysical Research Letters 40, 26892693. doi:10.1002/grl.50348

Vonk, J.E., Tank, S.E., Bowden, W.B., Laurion, I., Vincent, W.F., Alekseychik, P., Amyot, M., Billet, M.F., Canário, J., Cory, R.M., Deshpande, B.N., Helbig, M., Jammet, M., Karlsson, J., Larouche, J., MacMillan, G., Rautio, M., Walter Anthony, K.M., Wickland, K.P., 2015 a. Reviews and syntheses: Effects of permafrost thaw on Arctic aquatic ecosystems. Biogeosciences 12, 7129-7167.

Vonk, J.E., Tank, S.E., Mann, P.J., Spencer, R.G.M., Treat, C.C., Striegl, R.G., Abbott, B.W., Wickland, K.P., 2015b. Biodegradability of dissolved organic carbon in permafrost soils and aquatic systems: a meta-analysis. Biogeosciences 12, 6915-6930. doi:10.5194/bg-12-69152015

Walvoord, M.A., Kurylyk, B.L., 2016. Hydrologic Impacts of Thawing Permafrost-A Review. Vadose Zone Journal 15, 0-20. doi:10.2136/vzj2016.01.0010

Walvoord, M.A., Striegl, R.G., 2007. Increased groundwater to stream discharge from permafrost thawing in the Yukon River basin: Potential impacts on lateral export of carbon and nitrogen. Geophys. Res. Lett. 34. doi:10.1029/2007gl030216

Wang, G., Hu, H., Li, T., 2009. The influence of freeze-thaw cycles of active soil layer on surface runoff in a permafrost watershed. Journal of Hydrology 375, 438-449. doi:10.1016/j.jhydrol.2009.06.046

Wang, G., Ju, Q., Guodong, C., Yuanmin, L., 2002. Soil organic carbon pool of grassland soils on the Qinghai-Tibetan Plateau and its global implication. Science of the Total Environment, The 291, 207-217.

Wang, G., Li, Y., Wang, Y., Wu, Q., 2008. Effects of permafrost thawing on vegetation and soil carbon pool losses on the Qinghai-Tibet Plateau, China. Geoderma 143, 143-152. doi:10.1016/j.geoderma.2007.10.023

Wang, G., Liu, G., Li, C., Yan, Y., 2012. The variability of soil thermal and hydrological dynamics with vegetation cover in a permafrost region. Agricultural and Forest Meteorology 162-163, 44-57. doi:10.1016/j.agrformet.2012.04.006

Wang, G., Liu, G., Liu, L., 2011. Spatial scale effect on seasonal streamflows in permafrost catchments on the Qinghai-Tibet Plateau. Hydrol. Process. 26, 973-984. doi:10.1002/hyp.8187

Wang, G., Mao, T., Chang, J., Song, C., Huang, K., 2017. Processes of runoff generation operating during the spring and autumn seasons in a permafrost catchment on semi-arid

Peer) reviewing PDF | (2019:04:36338:1:1:NEW 15 May 2019) 
677

678

679

680

681

682

683

684

685

686

687

688

689

690

691

692

693

694

695

696

697

698

699

700

701

702

703

704

705

706

707

708

709

710

711

712

713

714

715

plateaus. Journal of Hydrology 550, 307-317. doi:10.1016/j.jhydrol.2017.05.020

Wiegner, T.N., Seitzinger, S.P., Glibert, P.M., Bronk, D.A., 2006. Bioavailability of dissolved organic nitrogen and carbon from nine rivers in the eastern United States. Aquat. Microb. Ecol. 43, 277-287. doi:10.3354/ame043277

Woo, M.-K., 2012. Permafrost Hydrology. Springer Science \& Business Media.

Wu, Q., Liu, Y., 2004. Ground temperature monitoring and its recent change in Qinghai-Tibet Plateau. Cold Regions Science and Technology 38, 85-92. doi:10.1016/S0165232X(03)00064-8

Wu, Q., Zhang, T., 2010. Changes in active layer thickness over the Qinghai-Tibetan Plateau from 1995 to 2007. J. Geophys. Res. 115, 347-12. doi:10.1029/2009JD012974

Wu, W., Yang, J., Xu, S., Yin, H., 2008. Geochemistry of the headwaters of the Yangtze River, Tongtian He and Jinsha Jiang: Silicate weathering and CO2 consumption. Applied Geochemistry 23, 3712-3727.

Yang, M., Nelson, F.E., Shiklomanov, N.I., Guo, D., Wan, G., 2010. Permafrost degradation and its environmental effects on the Tibetan Plateau: A review of recent research. Earth Science Reviews 103, 31-44. doi:10.1016/j.earscirev.2010.07.002

Yang, Y., Fang, J., Ji, C., Ma, W., Su, S., Tang, Z., 2010. Soil inorganic carbon stock in the Tibetan alpine grasslands. Global Biogeochemical Cycles 24, GB4022. doi:10.1029/2010GB003804

Yang, Y., Fang, J., TANG, Y., Ji, C., ZHENG, C., HE, J., ZHU, B., 2008. Storage, patterns and controls of soil organic carbon in the Tibetan grasslands. Glob Change Biol 14, 1592-1599. doi:10.1111/j.1365-2486.2008.01591.x

Zhang, B., Liu, F., Ding, J., Fang, K., Yang, G., Liu, L., Chen, Y., Li, F., Yang, Y., 2016. Soil inorganic carbon stock in alpine grasslands on the Qinghai-Xizang Plateau: An updated evaluation using deep cores. Chinese Journal of Plant Ecology 40, 93-101.

Zhang, T., Frauenfeld, O.W., Serreze, M.C., 2005. Spatial and temporal variability in active layer thickness over the Russian Arctic drainage basin. J. Geophys. Res. 110, 155. doi: 10.1029/2004jd005642

Zhao, L., Wu, X., Wang, Z., Sheng, Y., Fang, H., Zhao, Y., ... \& Mo, B. (2018). Soil organic carbon and total nitrogen pools in permafrost zones of the Qinghai-Tibetan Plateau. Scientific reports, 8(1), 3656.

Zimov, S.A., Schuur, E., Chapin, F.S., III, 2006. Permafrost and the global carbon budget. Science 312, 1612-1613.

Zolkos, S., Tank, S.E., Kokelj, S.V., 2018. Mineral Weathering and the Permafrost Carbon-Climate Feedback. Geophysical Research Letters.

Zou, D., Zhao, L., Sheng, Y., Chen, J., Hu, G., Wu, T., Wu, J., Xie, C., Wu, X., Pang, Q., Wang, W., Du, E., Li, W., Liu, G., Li, J., Qin, Y., Qiao, Y., Wang, Z., Shi, J., Cheng, G., 2017. A New Map of the Permafrost Distribution on the Tibetan Plateau. The Cryosphere 11, 25272542, doi: 10.5194/tc-11-2527-2017 


\section{Figure 1}

Map of the study area.

Map of the study area. Panel (a) shows the study watershed, while the white lines are boundaries of the sub-catchments. Sample sites and observation sites were marked on the map. The panel (b) shows the distribution of permafrost in the Qinghai-Tibet Plateau (Zou et al., 2017) . Panel (c) shows the location of the Qinghai-Tibet plateau. Figure parts were generated by ArcGIS Desktop 10.4 software (http://www.esri.com/software/arcgis). 


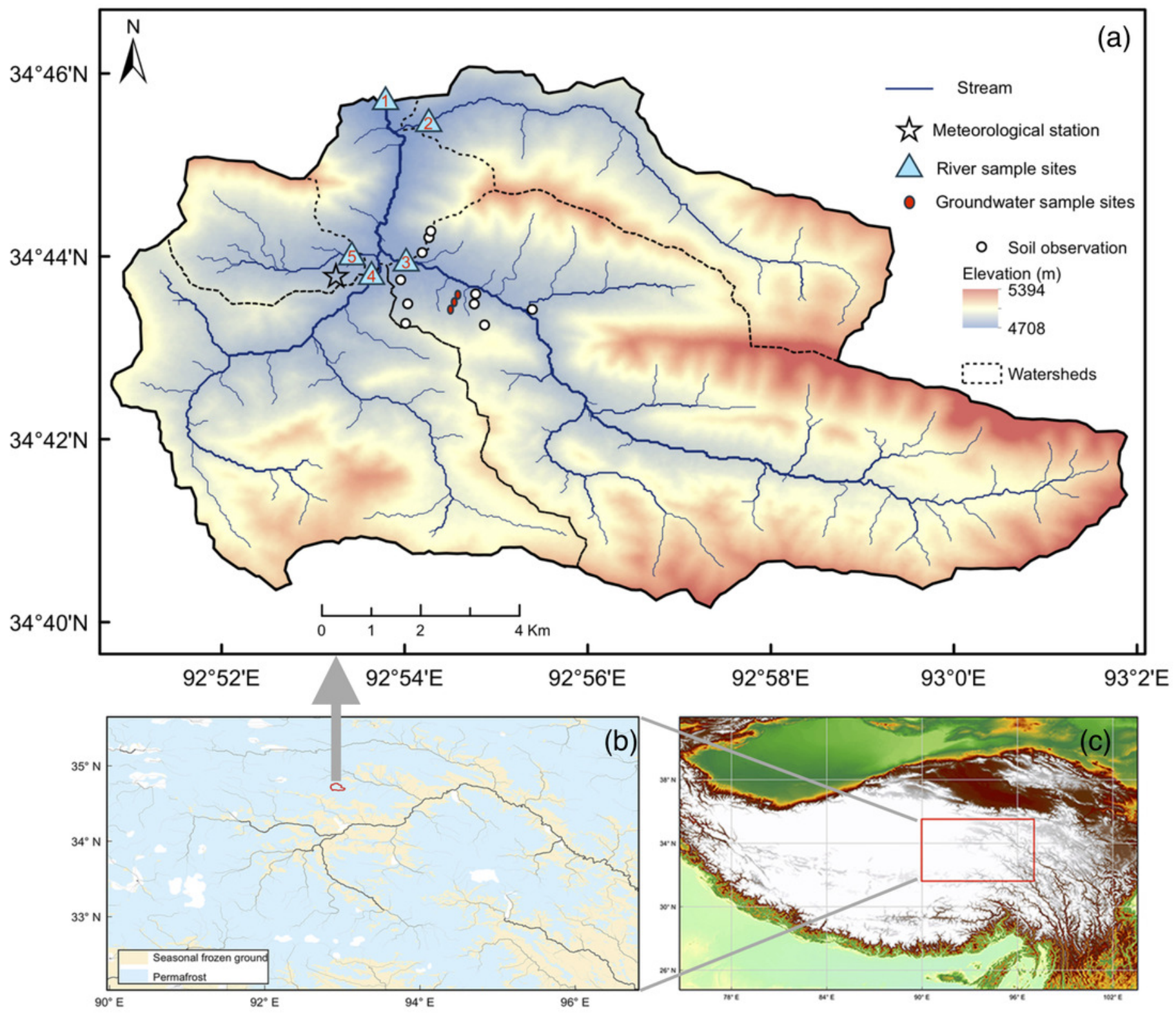




\section{Figure 2}

Runoff processes and time series of the riverine exported DIC and DOC concentrations at the outlet of Zuomaokong wa ter shed (catchment 1) during 2014 (a) and 2016 (b) freeze-free periods (May to October).

The round solid and circle points are directly observed data and the solid lines are calculated from LOADEST model results. Daily discharge and baseflow are displayed with gray shad es. The dashed straight lines are linear trends of measured DIC concentrations, while no significant trends were found for DOC concentrations. Note the linear trend lines based on

measured DIC: panel $a, y=0.11 x-5.71, R^{2}=0.72 ;$ panel $b, y=0.09 x+10.76, R^{2}=0.71 ; y$ represents DIC concentrations, $x$ represents the day of the year. 

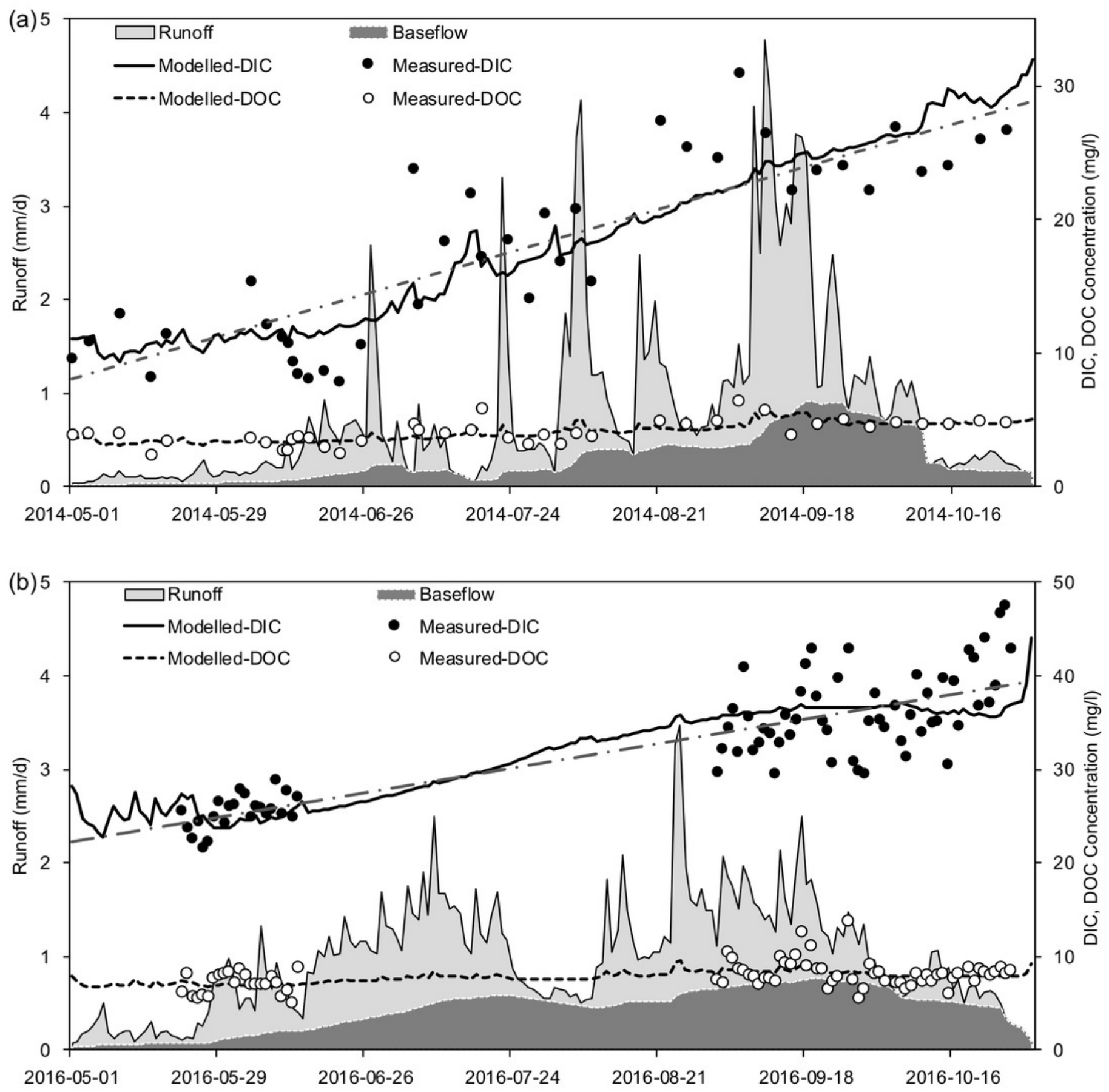
Figure 3

Figure 3. Monthly average DIC and DOC fluxes in $\mathrm{kg} / \mathrm{d}$, monthly total discharge and precipitation variations of the entire watershed (catchment 1) during 2014 and 2016. The error bars indicate the upper and lower $95 \%$ confidence intervals of LOADEST results

The error bars indicate the upper and lower 95\% confidence intervals of LOADEST results.

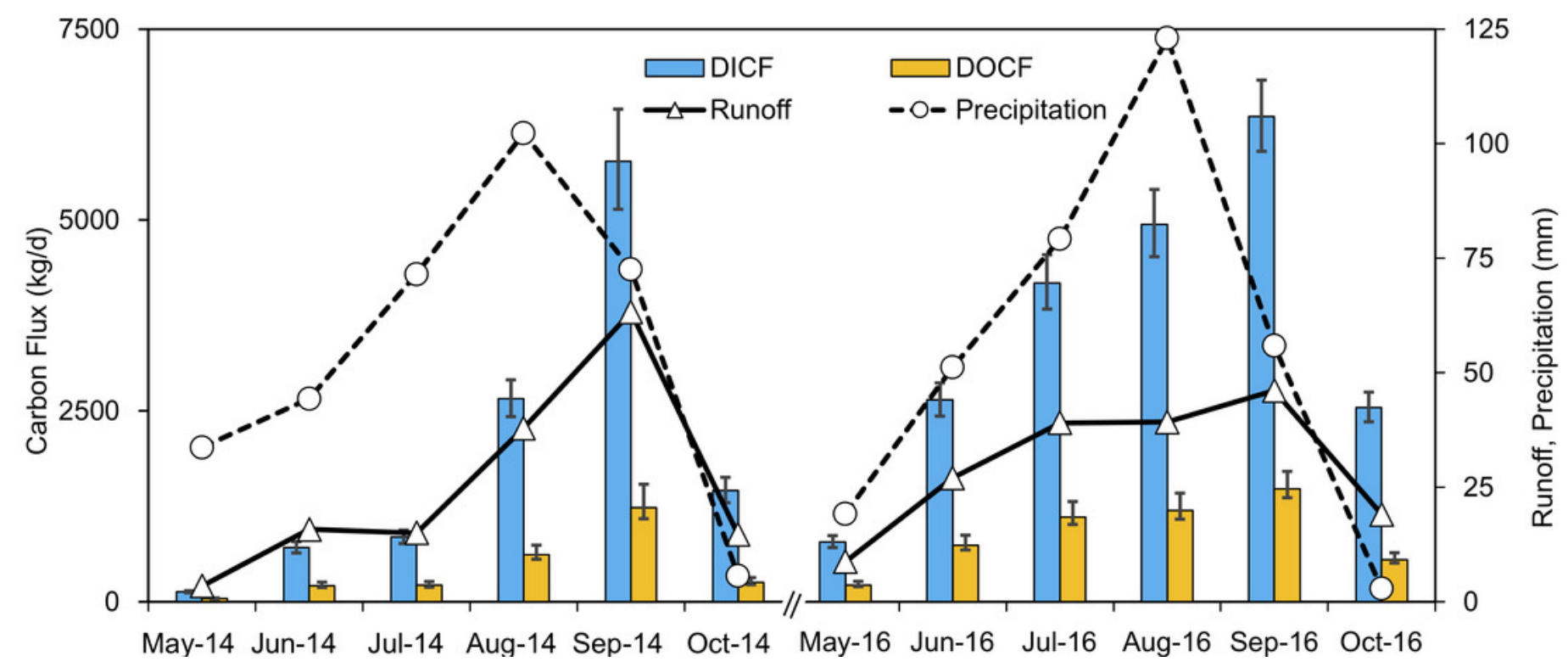




\section{Figure 4}

Correlation matrix plot indicate relationships of dissolved carbon concentrations and hydrological and meteorological factors.

The upper panel shows positive and negative Pearson's correlation coefficients in different size (larger represent higher values). Note significance values: $(*)$ for $p \leq 0.05 ;(* *)$ for $p \leq$ 0.01 ; and $(* * *)$ for $p \leq 0.001$. The red lines in lower panel are scaled kernel regression smoothers indicating potential linear and non-linear relationships. Q, discharge; BF, baseflow; $\mathrm{P}$, precipitation; $\mathrm{Ta}$, air temperature in ${ }^{\circ} \mathrm{C}$. 


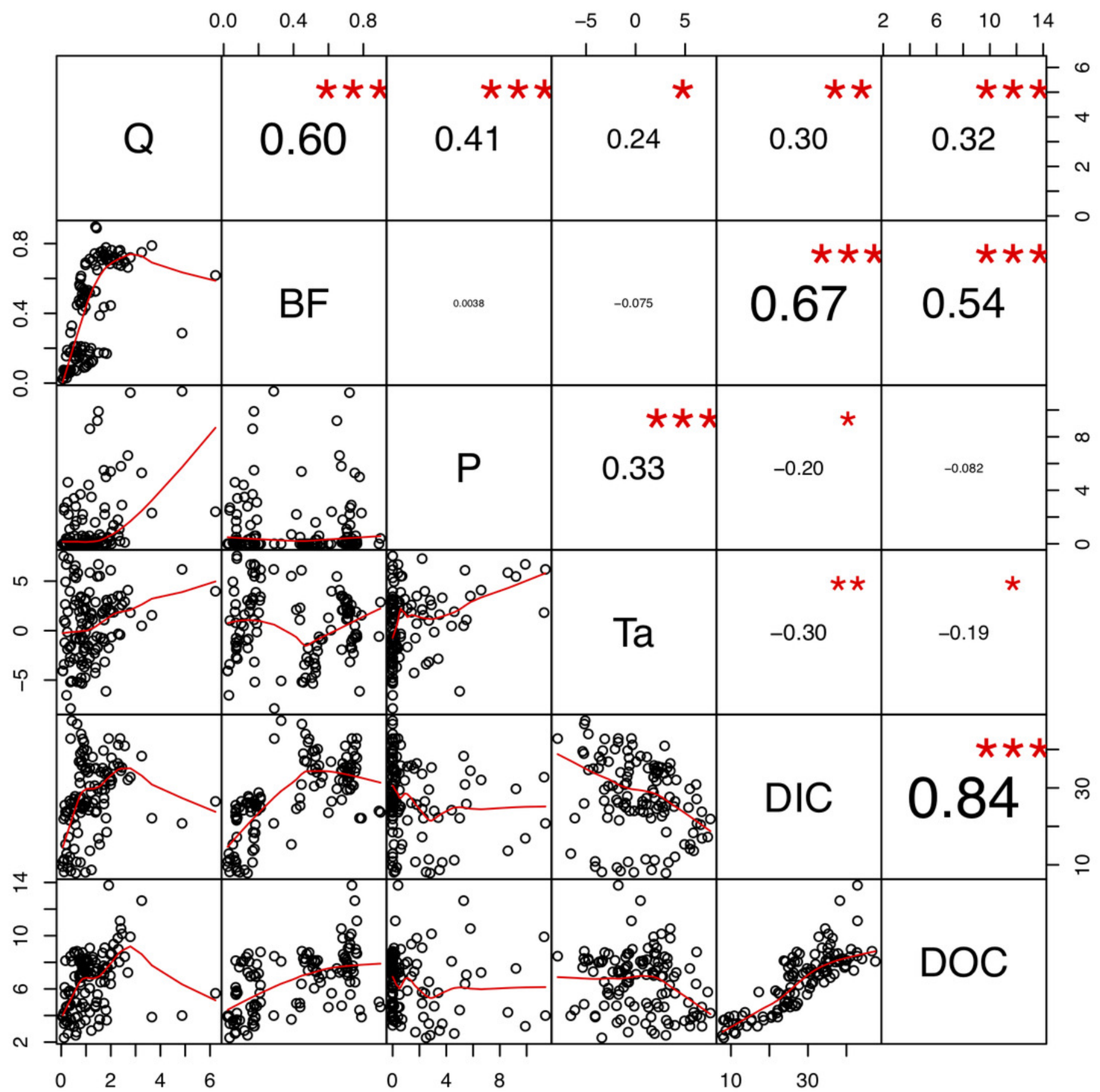


Figure 5

Relationships between catchment characteristics and dissolved carbon concentrations of the 5 catchments.

(a) vegetation coverage vs. dissolved carbon concentrations; (b) bare land coverage vs. dissolved carbon concentrations; (c) wetland coverage vs. dissolved carbon concentrations; (d) mean basin elevation vs. dissolved carbon concentrations; (e) catchment area vs. dissolved carbon concentrations. The round solid dots are DIC and the triangle dots are DOC. The $r$ is linear correlation coefficient. The shaded regions in the graphics are $95 \%$ confidence interval.
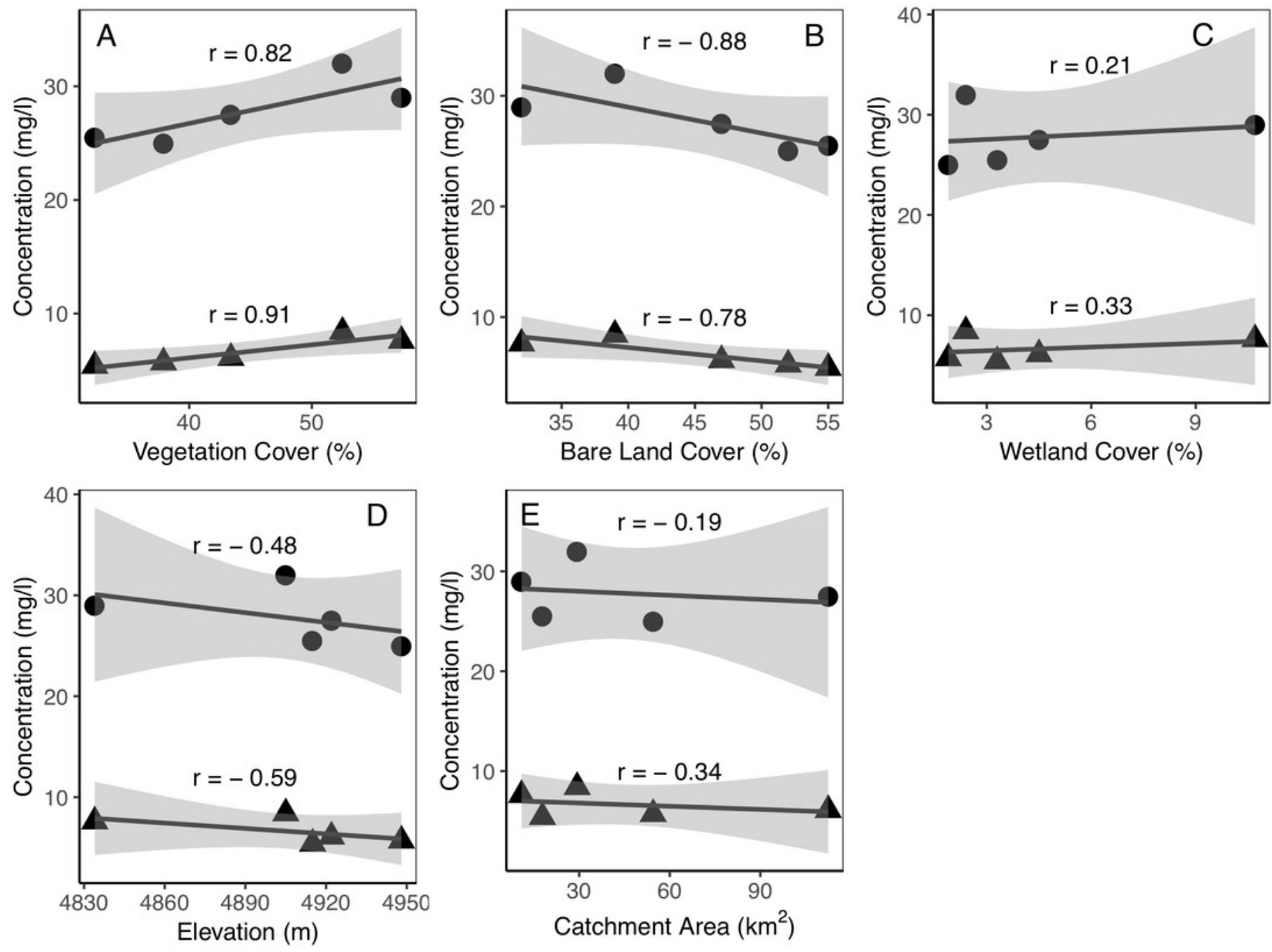
Figure 6

Relationships between active layer thawed depths and riverine dissolved carbon concentrations and fluxes during the thawing period in catchment 3 .

(a) Thawed depth vs. DIC concentration; (b) thawed depth vs. DIC flux; (c) thawed depth vs. DOC concentration; (d) thawed depth vs. DOC flux. The shaded regions in the graphics are 95\% confidence interval.
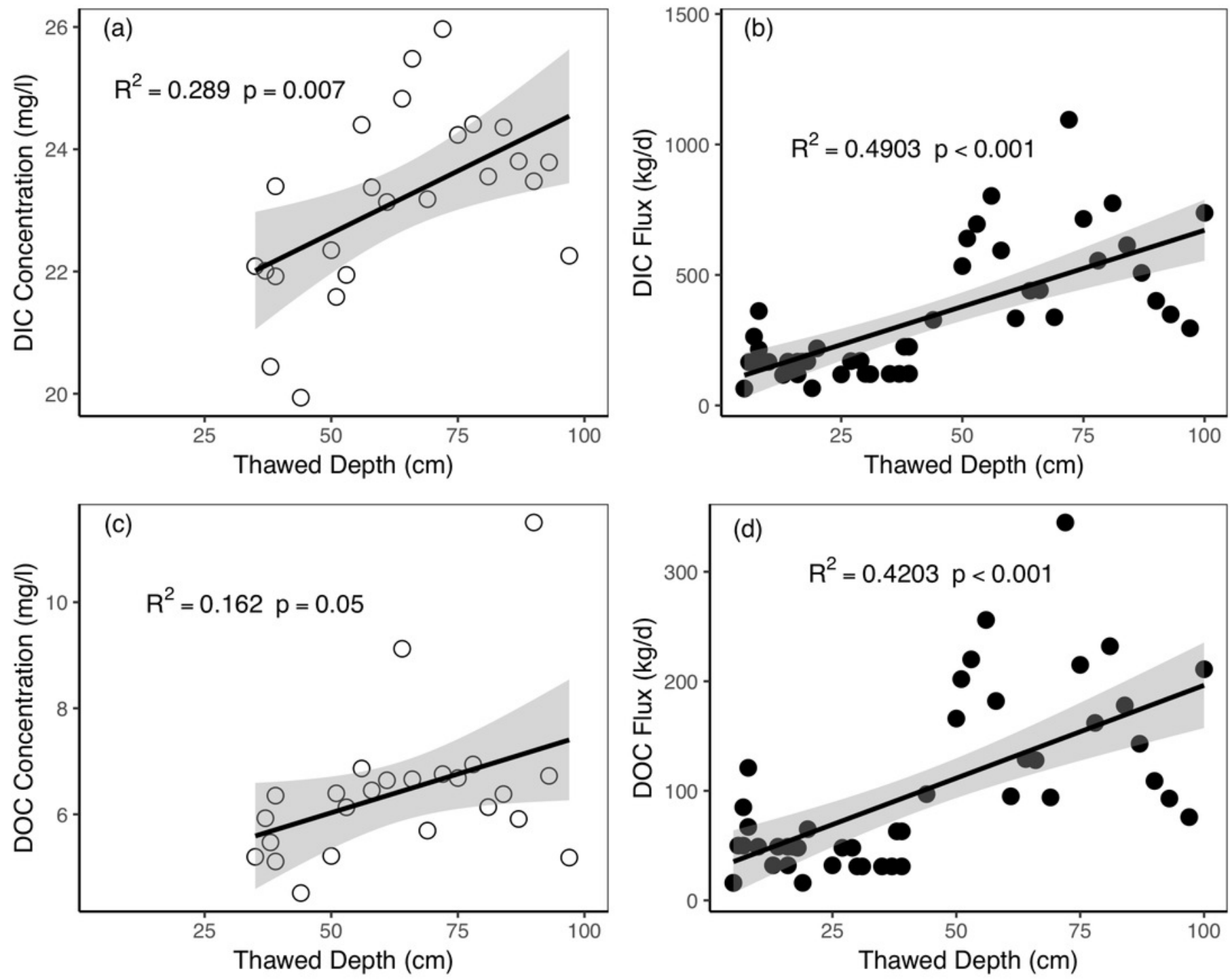
Figure 7

Relationships between active layer frozen depths and riverine dissolved carbon concentrations and fluxes during the freezing period in catchment 3.

(a) Frozen depth vs. DIC concentration; (b) frozen depth vs. DIC flux; (c) frozen depth vs. DOC concentration; (d) frozen depth vs. DOC flux.The shaded regions in the graphics are $95 \%$ confidence interval.
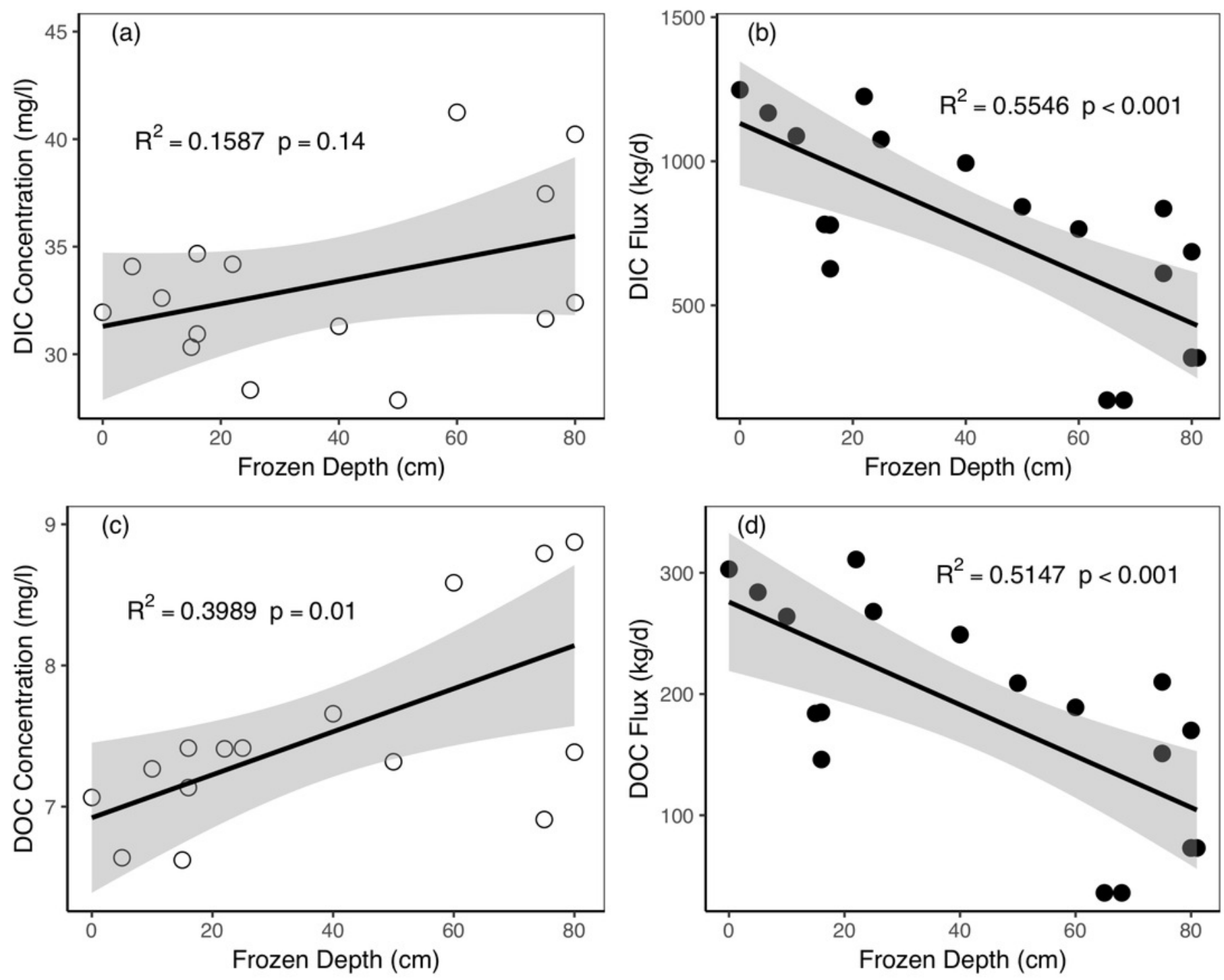
Figure 8

Conceptual diagrams of riverine carbon export in thawing (a) and freezing (b) period.

Red upward arrows mean increase and green downward arrows mean decrease. Blue arrows mean water flow and yellow arrows mean carbon flow. Thawed depth is the thawed thickness of the active layer, while frozen depth is the sum thickness of frozen part in the figure. 
(a) Thawing period

Active layer (thawed)

Air and soil temperature $\uparrow$

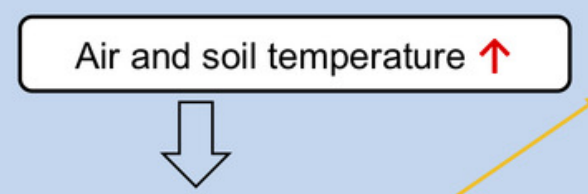

Active layer thawing from top to bottom

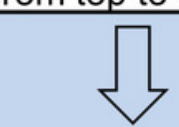
Soil water
content $\uparrow$

Precipitation $\uparrow$

1 | || DIC \& DOC

Surface runoff $\uparrow$

$\mathrm{CO}_{2}$

Infiltration

Thawed Organic C

Erode and rainwater DIC \& DOC

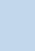




\section{Table 1 (on next page)}

Characteristics of the sub-catchments of the watershed.

Basin area and topography were obtained from ArcGIS 10.2 with GMTED2010 DEM data. Land cover of the basin were derived from SPOT-7 Satellite Images. 
1

\begin{tabular}{ccccccccc} 
Site & $\begin{array}{c}\text { Sampling sites coordinates } \\
\text { Latitude }\end{array}$ & $\begin{array}{c}\text { Area } \\
\left(\mathrm{km}^{2}\right)\end{array}$ & $\begin{array}{c}\text { Mean } \\
\text { elevatio } \\
\mathrm{n}(\mathrm{m})\end{array}$ & $\begin{array}{c}\text { Elevation } \\
\geq 5000 \mathrm{~m} \\
(\%)\end{array}$ & $\begin{array}{c}\text { Vegetatio } \\
\mathrm{n} \\
\text { coverage } \\
(\%)\end{array}$ & $\begin{array}{c}\text { Wetland } \\
\text { cover } \\
(\%)\end{array}$ & $\begin{array}{c}\text { Bare land } \\
\text { cover (\%) }\end{array}$ \\
\hline Catchment 1 & $34^{\circ} 45^{\prime} 48^{\prime \prime} \mathrm{N}$ & $92^{\circ} 53^{\prime} 49^{\prime \prime} \mathrm{E}$ & 117.0 & 4922 & 22.2 & 43.4 & 4.5 & 47 \\
Catchment 2 & $34^{\circ} 45^{\prime} 18^{\prime \prime} \mathrm{N}$ & $92^{\circ} 53^{\prime} 59^{\prime \prime} \mathrm{E}$ & 18.3 & 4915 & 20.2 & 32.3 & 3.3 & 55 \\
Catchment 3 & $34^{\circ} 44^{\prime} 8^{\prime \prime} \mathrm{N}$ & $92^{\circ} 53^{\prime} 45^{\prime \prime} \mathrm{E}$ & 56.4 & 4948 & 32.1 & 37.9 & 1.9 & 52 \\
Catchment 4 & $34^{\circ} 44^{\prime} 2^{\prime \prime} \mathrm{N}$ & $92^{\circ} 53^{\prime} 43^{\prime \prime} \mathrm{E}$ & 30.1 & 4905 & 10.5 & 52.5 & 2.4 & 39 \\
Catchment 5 & $34^{\circ} 44^{\prime} 2^{\prime \prime} \mathrm{N}$ & $92^{\circ} 53^{\prime} 42^{\prime \prime} \mathrm{E}$ & 6.8 & 4834 & 5.7 & 57.3 & 10.7 & 32 \\
\hline
\end{tabular}

2 


\section{Table 2 (on next page)}

Coefficients $\left( \pm S D\right.$ ) and $R^{2}$ values for LOADEST model $9\left[\ln (f l u x)=a_{0}+a_{1} \ln Q+a_{2} \ln Q^{2}+\right.$ $\mathrm{a}_{3} \operatorname{Sin}(2 \pi d t i m e)+\mathrm{a}_{4} \operatorname{Cos}(2 \pi d t i m e)+\mathrm{a}_{5} d t i m e+\mathrm{a}_{6} d t i m e[\sup ]$

Flux in $\mathrm{kg} / \mathrm{d}, \mathrm{Q}$ in $\mathrm{ft}^{3} / \mathrm{s}, \ln \mathrm{Q}=\ln ($ streamflow) - center of $\ln ($ streamflow), dtime = decimal time center of decimal time. 
1

\begin{tabular}{lllllllll} 
& $\mathrm{R}^{2}$ & $\mathrm{a}_{0}$ & $\mathrm{a}_{1}$ & $\mathrm{a}_{2}$ & $\mathrm{a}_{3}$ & $\mathrm{a}_{4}$ & $\mathrm{a}_{5}$ & $\mathrm{a}_{6}$ \\
\hline DIC & 0.9836 & $7.4367 \pm$ & $0.942 \pm$ & $0.0289 \pm$ & $0.3108 \pm$ & $0.1856 \pm$ & $0.2869 \pm$ & $-0.4002 \pm$ \\
& & 0.0756 & 0.0275 & 0.0137 & 0.0256 & 0.0813 & 0.0185 & 0.055 \\
\multirow{2}{*}{ DOC } & \multirow{2}{*}{0.9794} & $5.8034 \pm$ & $1.0102 \pm$ & $0.047 \pm$ & $0.0749 \pm$ & $0.049 \pm$ & $0.3158 \pm$ & $-0.1727 \pm$ \\
& & 0.0805 & 0.0293 & 0.0146 & 0.0273 & 0.0866 & 0.0197 & 0.0585
\end{tabular}

2 


\section{Table 3 (on next page)}

Dissolved carbon concentrations ( $\mathrm{mg} \mathrm{C} \mathrm{L}^{-1}$ ) of stream water, precipitation, and groundwater in 2014 and 2016 freeze-free seasons.

DIC concentration is significantly higher than DOC for all the sampling sites. Sampling locations are marked in Figure 1a. $\mathrm{N}$ column is the sample size. 
1

\begin{tabular}{llll} 
Sampling location & Variables & N & Mean $( \pm$ SD $)$ \\
\hline Catchment 1 & DIC & 117 & $27.81( \pm 9.75)$ \\
& DOC & 117 & $6.57( \pm 2.24)$ \\
Catchment 2 & DIC & 111 & $27.14( \pm 7.60)$ \\
& DOC & 111 & $5.92( \pm 1.76)$ \\
Catchment 3 & DIC & 117 & $26.92( \pm 9.80)$ \\
& DOC & 117 & $6.36( \pm 2.17)$ \\
Catchment 4 & DIC & 109 & $31.98( \pm 9.90)$ \\
& DOC & 109 & $9.34( \pm 5.97)$ \\
Catchment 5 & DIC & 111 & $29.89( \pm 11.42)$ \\
& DOC & 111 & $7.91( \pm 2.94)$ \\
Precipitation & DIC & 52 & $3.08( \pm 1.93)$ \\
& DOC & 52 & $2.66( \pm 1.93)$ \\
Groundwater & DIC & 56 & $59.28( \pm 16.58)$ \\
& DOC & 56 & $11.59( \pm 2.53)$ \\
\hline
\end{tabular}

2 